\title{
ULTRASOUNDWAVE TREATMENT OF CHRONIC DISORDERS OF THE LOCOMOTOR SYSTEM
}

\author{
BY \\ ARNOLD SONNENSCHEIN \\ Vienna University, Orthopaedic Department
}

Treatment with ultrasoundwaves is the latest method of physical therapy to attract attention in many countries. Langevin and others (1923) first proved the existence of biological effects of ultrasoundwaves in experiments in which they killed small fishes. Pohlman and his co-workers (1939) used ultrasoundwaves in the treatment of sciatic pain and other neuralgias. But only since 1945 has it become possible to build and distribute ultrasoundwave apparatus so that their effects could be studied on a wider scale. These results have been acclaimed as successful, besides being subjected to severe criticism.

Definition.-The name ultrasound (U.S.) is given to a "sound " produced by more than 18,000 mechanical vibrations per sec. which is not audible to the human ear.

Production.-This high frequency can be produced with the aid of magnetic effects (Joule) by introducing a nickel rod into a magnetic field where it may vibrate at a rate of 100,000 or even 170,000 longitudinal vibrations per sec. The frequency can be further increased by making use of the piezo-electric effect (Curie). Here a quartz-crystal plate, cut at right angles to its axis, is introduced into an electrical alternating field of high frequency. The plate then vibrates at more than 300,000 vibrations per sec.

The number of vibrations depends on the thickness of the plate. For medical purposes a frequency of $800,000 \mathrm{vib}$./sec. is commonly used, and the plate is $3.6 \mathrm{~mm}$. thick. Quite often therapeutic frequencies of 450,000 to $1,200,000 \mathrm{vib}$./sec. are selected (kilocycles). For experimental purposes, frequencies up to three times this therapeutic range can be achieved.

When the frequency of the electrical alternating field is made to coincide with that of the mechanical vibrations of the quartz plate, maximal vibration amplitudes can be produced which result in optimal effectiveness.

The ultrasoundwaves are conducted from the quartz plate on to a flexible metallic diaphragm, which together with the high tension cable and cooling system constitutes the "transducer head".

Dosage.-For therapeutic use a method of dosage is essential. Apart from the frequency the effective output can be measured. This is calculated from the high-frequency energy which reaches the quartz plate. 
In ultrasound apparatus of 800 kilocycles this effective output amounts to 3 to 4 watts per square centimetre $\left(\mathrm{cm}^{2}{ }^{2}\right)$. In this way, however, we can measure only the energy which reaches the plate and not that which is directed from the plate on to the body. This is limited by many factors.

Effect in Depth.-Vibration-frequency determines not only the wavelength but also the effect in depth. The higher the frequency the greater the absorption and the smaller the action in depth. Action in depth is measured with the aid of " half-value depth", i.e. a layer of such thickness as is required to halve the ultrasoundwave intensity. In an ultrasound apparatus of 800 kilocycles this value is about $5 \mathrm{~cm}$.; for this reason this frequency is most often used in therapeutic work.

Intensity diminishes geometrically. Therefore we find sufficient sound-wave action for therapeutic effects to be obtained at even greater depths. The effective maximum also depends on the size of the diaphragm, owing to "bundling", of the sound waves. Small membranes, measuring $25 \mathrm{~mm}$. across, show a maximum intensity at a depth of $5 \mathrm{~cm}$.; larger membranes, $40 \mathrm{~mm}$. across, concentrate the radiation at $20 \mathrm{~cm}$. depth (Pohlman).

\section{Methods of Application}

For the soundwave treatment of large areas with thick layers, large soundradiation heads are to be preferred, in other cases the smaller head will be found more useful.

The " soundfield" derived from the membrane is subject to complex influences which render dosage-in any case not very reliable-inaccurate. The soundfield contains a centre of high intensity surrounded by a periphery of less intense sound waves.

The volume of sound radiation actually transmitted depends on absorption, permeability, and " beam characteristics" in the various parts of the body and on the varying density of the tissues.

Finally, the very short soundwaves lead to the formation of " standing waves" close together, so that adjacent areas of the body may receive uneven amounts of radiation.

In order to minimize this unevenness, the sound-radiation head ought to be kept constantly moving so as to make a more even distribution of sound intensity possible. The sharp demarcation between sound hills and sound dales can thus be eliminated.

If, however, the sound-head is worked by hand, there is the danger of its uneven application and of tilting. This leads to air-gaps which the radiation will have to bridge instead of entering the body directly. Like optic radiation, ultrasound radiation is reflected at a boundary surface on its path from one medium to another. Sound radiation is reflected 100 per cent. on its way from the sound membrane into the air, and is therefore altogether lost for therapeutic purposes.

To prevent this, a fluid can be inserted between the sound-head and the body surface which reduces reflection to some 30 per cent. In therapeutic work liquid 
paraffin (ol. paraffini) is used which is painted on to the skin. In the larger areas of the body (shoulder, back, buttocks, abdomen) the sound-head will then glide closely and smoothly over the skin.

But in the extremities, particularly in sparely built patients, the unevenness of the surfaces would lead to gaps between sound-head and skin and much energy would be lost; such cases are treated in the bath, under water, and the sound-head is moved parallel to the extremity at a distance of 5 to $6 \mathrm{~cm}$.

Accurate dosage of effective ultrasound energy is difficult, if not impossible, as we have seen when dealing with reflection, bundling, absorption, dispersion in the tissues, loss of intensity, and effective action in depth. In addition, the time factor must be taken into account. This is essential for an understanding of the therapeutic effect on the tissues, but has been neglected or altogether omitted in many published papers.

In spite of these difficulties, ultrasoundwaves are used as a therapeutic agent. Their effects have been studied, and-in part-demonstrated, in animal experiments (Barth and Bülow, 1949; Dykgraaf, 1933; Mayno, 1949; Peters, 1949; Schmitz, 1949), and in physical (Brüner and Rindfleisch, 1947; Giacomini, 1949; Pohlman, 1949), biological (Bode and Theisman, 1949; Breuning, 1949; Stuhlfauth and Wuttge, 1949), and histological (Dyroff and Horvath, 1944; Peters, 1949) investigations.

It has been found that irreversible damage to tissues results only if the usual therapeutic dosage is exceeded.

\section{Mode of Action}

As far as can be seen at present, three factors can be isolated in the as yet incompletely understood mechanism of ultrasound treatment:

(a) Local hyperthermy caused by absorption of energy in the tissues. With 800 kilocycles and a sound bundle of $20 \mathrm{~mm}$. diameter this amounts to a rise of temperature of $5^{\circ} \mathrm{C}$. at a depth of $5 \mathrm{~cm}$. (Pohlman). This is a maximum which develops only at the sites of the greatest compression of the tissue under static ultrasoundwaves. Since, however, treatment with higher frequency will usually be undertaken with a mobile sound-head, local hyperthermy is so small and transient that it can be neglected. According to Krebs (1949) the average heating effect cannot be made responsible for therapeutic success, since therapeutic improvement after sound treatment was seen in cases where shortwave treatment was without effect.

(b) The main effect, therefore, appears to be due to mechanical factors, since the range of vibration of particles will be $4 \cdot 4$ to $10^{-6} \mathrm{~cm}$. with an acceleration of $22.4 \mathrm{~cm}$. $/ \mathrm{sec}$. if the energy used is 800 kilocycles $/ \mathrm{sec}$. and $4 \mathrm{watts} / \mathrm{cm} .^{2}$ (Pohlman). With rapid acceleration and an increase of intensity there appear considerable disruptive forces in the tissues. Cell-groups are torn out of continuity and differences in density between cellular cytoplasm and nucleus lead to submicroscopical lesions within the cell. With a further increase of ultrasound energy fluid-particles may explode. The so-called cavitation is produced which consists 
in the formation of cavities which are at first blown open and immediately compressed again. Since the tissues are not very compressible, an alternation of high and low pressures results which rises and falls 800,000 times per sec., from plus 3.7 to minus 3.7 atmospheres.

At a frequency of 800 kilocycles/sec., the wavelength is $2 \mathrm{~mm}$. The fall of pressure occurs within half a wavelength, so that there is a momentary fall in pressure of 7.4 atmospheres per millimetre. This results in intensive micromassage of the tissue, encourages the fluid exchange and favours intracellular metabolism. The alternating pumping action leads to hyperaemia and hyperlymphia of the tissues and improves local fluid increases and their distribution.

(c) There will be further molecular changes in the tissues due to colloid-osmotic and chemical reactions.

According to Pohlman (1949) it may be assumed that, with high intensities, long-chained protein molecules are being split and intermediate metabolites formed. The fluid content of certain colloidal systems is being changed, since ultrasoundwaves have the power to drive fluid into shrunken tissues and thereby increase their water content and lead to softening of hardened parts of tissue.

Ultrasoundwaves, when properly applied, may diminish pain and reduce irritability of segmental nerve-endings. They may lessen the spasm of regional muscle-groups. With blood- and lymph-flow mechanically improved, chronic inflammatory products can be removed and the process of healing encouraged. At the same time the fluid content of the tissues and their permeability is increased. Sclerosed and indurated scars may become more resilient and elastic.

The hypothesis of some authors (Krebs, 1949; Pohlman, 1949), that ultrasoundwaves have bactericidal powers, still awaits proof. But it is not unlikely that an increase in phagocytosis and immunobiological reactions might follow the increased blood- and lymph-supply.

Since the therapeutic effect depends largely on mechanical influences, it is obvious that ultrasoundwave therapy is contra-indicated in acute inflammatory conditions, where it would lead to reactivation and exacerbation.

\section{Clinical Results}

150 patients suffering from chronic conditions of the locomotor system were submitted to a test of the effectiveness of ultrasoundwaves. They all had had treatment with various physical methods (mud-packs, diathermy, short-wave diathermy, in some cases $x$ rays) either in our department or elsewhere.

The period of treatment and follow-up extends to April, 1949. In most cases, therefore, the patients were followed up for one year.

Aseptic periostitis tibiae, " tennis elbow", subdeltoid bursitis, acromial bursitis, and calcaneal spur.-Twenty cases were treated in five to eight sessions of 5 to $8 \mathrm{~min}$. duration. In 70 per cent. pain was abolished and function restored. It is important to emphasize that in such cases the intensity of ultrasound treatment must not exceed 2 to 2.5 watts $/ \mathrm{cm}^{2}$. Otherwise an uncomfortable, burning, 
periosteal pain will be produced. Several of these patients had previously been treated with repeated injections of Novocain without success.

Long-standing muscular rheumatism, lumbago, and resistant myalgias of the shoulder or hip.-In twenty cases the treatment proved successful, as also in cases: of gluteal myalgias. The mechanical effect of ultrasound therapy is easier to understand when it is seen to be successful in this group, and also with such patients as pianists, typists, and ballet dancers, whose work may lead to chronically painful induration of muscle groups. Eight to ten treatments of about $10 \mathrm{~min}$. duration using an intensity of 3.5 watts $/ \mathrm{cm}^{2}{ }^{2}$ are required. Alcohol-compresses applied in the evening proved a valuable addition.

Disturbances of the peripheral circulation.-Of five patients treated, an increase in the blood-supply could be achieved in two cases of intermittent claudication. Treatments of moderate intensity ( 2 to 2.5 watts $\left./ \mathrm{cm} .{ }^{2}\right)$ were given for slowly increasing periods of from 3 to $10 \mathrm{~min}$. The sound-head was moved along the course of the arteries in front of the foot, along the calf and along the anterior surface of the thigh up to the groin. The spasms in the region of the calf disappeared, the local temperature of the dorsum pedis returned to normal, and there was a measurable oscillometric improvement.

Thrombo-angiitis obliterans and Raynaud's disease.-With these cases no success was achieved. The follow-up period has been very short, and such successes as have been observed both by us and by others are unreliable. It is advisable, therefore, not to confine treatment of this group to the ultrasound therapy, but to combine with it the more usual medical and surgical procedures.

Post-traumatic joint changes after contusion or sprain.-These often appear negligible and are underrated by the doctor. Beyond some circumscribed tenderness near the insertion of a ligament no objective findings may be elicited. But the patient suffers from a considerable limitation of function against which most other methods are powerless. Here, it appears, ultrasound treatment is the method of choice. In thirty patients with pain after contusions and sprains of knee, ankle, or elbow, four to six treatments of $10 \mathrm{~min}$. duration abolished all symptoms.

Arthritic changes:

Degenerative arthritis of the hip, knee, and ankle-joints.-25 patients were treated, but only at the ankle was there a favourable response after ten treatments at 4 watts $/ \mathrm{cm} .{ }^{2}$ for 10 to $15 \mathrm{~min}$., when pain on weight bearing and movement was reduced. Arthritis of the knee responded according to whether inflammatory or degenerative changes preponderated. Only in inflammatory cases did we see a temporary improvement with painless intervals. In osteo-arthritis of the hip no success was recorded. This can be easily understood, for the often considerable fat pad in this region prevents penetration.

Inflammatory joint changes (mostly rheumatoid arthritis). -25 patients were treated; there were not only capsular changes but fully developed contractures. In all joints except the hip-joint reduction of pain and muscular spasm occurred after ten to fifteen treatments of $10 \mathrm{~min}$. duration at 4 watts $/ \mathrm{cm} .{ }^{2}$. Some softening 
of periarticular tissues occurred, particularly near the shoulder, and we had the impression that ultrasound treatment has a softening fibrolytic effect on sclerosed tissues (Denier, 1948). The relief of painful rigidity, which is the prerequisite for mobilization and correction of deformity, can thus be achieved; but the curative effect requires passive movements and other orthopaedic measures. In this way important improvement of chronically inflamed joints can be attained, provided the patient co-operates and there is no rheumatic flare-up.

Chronic inflammatory changes of the small intervertebral joints.-Cases of arthritis of the spine, and particularly of spondylitis deformans (eighteen patients), responded very differently. Rheumatic or infective spinal arthritis can successfully be treated with short wave, but spondylitis ankylopoietica (Bechtérew) is refractory to most attempts at therapy and eventually leads to ankylosis not only of the whole spine but of other joints as well. With Hintzelmann (1949a, b), we found that ultrasound treatment gives results which are as good or better than those claimed for any other therapeutic method. It appears to cause softening of the contracted capsules and fibrotic periarticular tissues. Joints which did not yet show an osseous ankylosis gained in mobility and the excursion of the chest improved considerably. In some cases mobility improved to such an extent that the kyphotic spine straightened up. Fourteen to twenty treatments of $15 \mathrm{~min}$. duration at 4 to $4.5 \mathrm{watts} / \mathrm{cm}^{2}$ were required.

The average blood-sedimentation rate was raised by 20 to $25 \mathrm{~mm}$. after the first few sittings. Two months after the end of the course the blood sedimentation rate fell below initial values. Orthopaedic measures (extension and corset) and mudbaths were also used.

Neurological Considerations.- - It is important to note that in treating the spinal column the sound-head must be guided so that the soundwaves diverge from the midline, i.e. the sound-head must be tilted away from the cord. If this is not done, a temporary irritation of the cord or roots is produced. In two cases of spondylarthritis where this precaution was neglected, treatment was followed by violent spasms in the lower limbs for 3 hours with flexion in hips and knees. We had a similar experience in the region of the knee in a pationt suffering from post-traumatic pain, who had violent spasms of the muscles of the calf immediately after treatment but not otherwise. The facts that these spasms always followed treatment with ultrasoundwaves and were situated in areas supplied by nerve-trunks within the treated region make it impossible to deny the causal connection between ultrasound treatment and nerve-irritation.

These findings dissuaded us, in contrast to the recommendations of Fierz and Denecke (1949), Niemöller (1949), and Pohlman (1949), from using ultrasound treatment in neurological cases, sciatic pain, and cases of neuritis. If the effects of the ultrasound, the mechanical tissue tensions, the pressure changes, and the acceleration of particles, are remembered, one cannot help fearing the danger of irreversible tissue damage in the inelastic nerve-structures. Follow-up investigations in cases of neuritis treated with ultrasound have extended over several years, but have not yet proved that no harm is being done. 
Peters (1949), Schmitz (1949), and Krejci and Bejdl (1950) have confirmed our view in animal experiments. They have shown in the guinea-pig the formation of vacuoles and changes in the thickness of the myelin sheath of the sciatic nerve after ultrasound treatment with 500 kilocycles at 1.8 to 3.5 watts $/ \mathrm{cm}^{2}$ for 4 to $10 \mathrm{~min}$. This shows the intense action of ultrasound and degeneration of nervous tissue. It would seem that these changes are due to colloid-osmotic influences.

We can, however, make use of ultrasound in neurological conditions where the consequences of degeneration do not lead to harmful effects. This applies to cases of causalgia in amputation stumps where all other conservative and surgical attempts failed. In seven cases we had a lasting success after ten treatments at 4 watts $/ \mathrm{cm}^{2}$.

\section{Conclusions}

Summing up we see in ultrasound treatment a method successful in a number of disorders of the locomotor system which differs in principle from other physical modes of treatment owing to its characteristic mechanical way of action. Since dosage is still inaccurate and many of the effects are still unexplained, much further experimental and clinical work will have to be added before ultrasound can be more widely used in practice.

Only when we know more exactly the efficiency of ultrasound and its limitations, only if we can be more certain of the proper indications, shall we be able to call ultrasound therapy, alone or in combination with other methods, a valuable new asset to our therapeutic resources.

\section{REFERENCES}

Barth, G., and Bülow, H. A. (1949). Strahlentherapie, 79, 271.

Bode, H., and Theisman, H. (1949). In "Der Ultraschall in der Medizin ", p. 291. Hirzel, Zürich. Breuning, E. (1949). Ibid., p. 139.

Brüner, H., and Rindfleisch, H. (1947). Naturwiss., 34, 347.

Denier, A. (1948). J. belge Radiol., 31, 213.

Dykgraaf, S. (1933). Z Z vergl. Physiol., $20,162$.

Dyroff, R., and Horvath, J. (1944). Strahlentherapie, 75, 126.

Fierz, F., and Denecke, L. (1949). Schweiz. med. Wschr., 79, 1109.

Giacomini, A. (1949). Nuovo Cim., N.S., 6, 39.

Hintzelmann, U. (1949a). Dtsch. med. Wschr., 74, 869.

- (1949b). Schweiz. med. Wschr., 79, 759.

Krebs, J. (1949). “Ultraschalltherapie". Pagenkämpfer, Osnabrück.

Krejci, F., and Bejdl, W. (1950). Pract. oto-rhino-laryng., 12, 193.

Langevin, P., Chilowsky, C., and Tournier, M. (1923). J. Phys. Radium, 6 ser., 4, 537.

Mayno, G. (1949). In “ Der Ultraschall in der Medizin ”, p. 205. Hirzel, Zürich.

Niemöller, H. K. (1949). Dtsch. med. Wschr., 74, 871.

Peters, G. (1949). In "Der Ultraschall in der Medizin ”, p. 167. Hirzel, Zürich.

Pohlman, R. (1949). Schweiz. med. Wschr., 79, 754.

-, Richter, R., and Parow, E. (1939). Disch. med. Wschr., 65, 251.

Schmitz, W. (1949). In " Der Ultraschall in der Medizin”, p. 171. Hirzel, Zürich.

Stuhlfauth, K., and Wuttge, K. H. (1949). Klin. Wschr., 27, 662.

\section{Additional Bibliography of Relevant Articles}

Born, H. (1949). Strahlentherapie, 79, 513.

Buchtala, V. (1949). Schweiz. med. Wschr., 79, 412.

Desgrez, H., and Malinvaux, J. (1949). Paris méd., 39, 354.

Dussik, K. (1949). Wien. klin. Wschr., 61, 246.

Horatz, K. (1949). Strahlentherapie, 79, 635.

Schliephake, E. (1949). Ibid., 79, 613.

Ungeheuer, E. (1949). Ibid., 79, 619. 
Traitement des affections chroniques du système locomoteur par des ondes ultra-sonores

\section{RÉSUMÉ}

L'auteur définit la thérapie par des ondes ultra-sonores et décrit les méthodes de production et de transmission des ondes de haute fréquence, ainsi que les moyens de les mesurer et appliquer en doses thérapeutiques efficaces.

Bien que l'action thérapeutique des ondes ultra-sonores puisse s'exercer partiellement par l'intermédiaire d'une hyperthermie locale, leur effet principal est dû à l'intense micro-massage suivi d'une hyperthermie et d'une hyperlymphie tissulaire et à des altérations moléculaires consécutives à des réactions chimiques et colloỉdo-osmotiques.

L'analyse des résultats du traitement de 150 cas de différents types de rhumatisme montre qu'ils furent les meilleurs dans le rheumatisme musculaire, le lumbago et dans les myalgies de l'épaule et de la hanche.

Dans les atteintes articulaires les ondes ultra-sonores constituent un adjuvant thérapeutique utile, car elles suppriment la rigidité douloureuse, permettant ainsi la mobilisation et la correction de la position articulaire.

Le traitement est contre-indiqué en cas d'inflammation aiguë et il faut bien soigner de ne pas irriter la moelle épinière et les racines nerveuses. En cas de dégénérescence nerveuse établie, comme dans la causalgie des moignons d'amputation, des effets néfastes ne sont plus à craindre et le traitement réussit mieux.

- Pour déterminer exactement la portée de la thérapie par des ondes ultra-sonores, une corroboration expérimentale plus ample est nécessaire.

\section{El tratamiento de las afecciones crónicas del sistema locomotor por ondas ultra-sonoras}

SUMARIO

Después de definir la terapia por ondas ultra-sonoras, el autor describe los métodos de producción y de transmisión de las ondas de alta frecuencia así como los medios para medir y aplicarlas en dosis terapéuticas eficaces.

Aunque la acción terapéutica de las ondas ultra-sonoras pudiera ejercerse en parte por intermedio de una hipertermia local, su efecto principal se debe a un micromasaje intensivo, seguido de hiperemia y de hiperlimfia tisular y de alteraciones moleculares consecutivas a reacciones químicas y coloido-osmóticas.

El análisis de los resultados del tratamiento de 150 casos de varios tipos de reumatismo muestra que los efectos más favorables fueron en el reumatismo muscular, en el lumbago y en las mialgias del hombro y de la cadera. En la enfermedad articular las ondas ultra-sonoras contribuyen a la recuperación porque suprimen la rigidez dolorosa y permiten la movilización y la corrección de la posición articular.

El tratamiento es contraindicado en casos de inflamación aguda y hay que evitar cuidadosamente una irritación de la médula espinosa y de las raices nerviosas. En casos de degeneración nerviosa establecida, como en la causalgia de un muñón, ya no se puede hacer daño y el tratamiento da buenos resultados.

Se necesitan más experimentos para poder determinar exactamente la posición de la terapia por ondas ultra-sonoras. 